\title{
About Some Manifestations of Antonymy and Synonymy in the Terminology of Economics
}

\author{
Prof. Ass. Dr. Sadete Pllana \\ University of Prishtina "Hasan Prishtina", Faculty of Economics \\ Email: sadete.pllana@uni-pr.edu \\ Mr. Sc. Gani Pllana, PhD Student \\ University of Prishtina "Hasan Prishtina", Faculty of Mechanical Engineering \\ Email: gani_pllana2012@hotmail.com
}

Doi:10.5901/mjss.2014.v5n13p434

\begin{abstract}
In terminology, different from the general language, the synonymy was considered as a harmful occurrence in handling the problems of terminology, but acceptable. On the platform of general language, it is difficult to study the terminological lexicon in the synonymic connections as separate entities, unless they are viewed as an integrated lexicon in the general lexicon. It becomes possible to study the synonymy in terminology within a field of knowledge, like polysemy and homonymy. In terminology synonymous connections are built on the base of semantic equivalents and as such they impinge the system, although they appear for internal and external linguistic causes, which lead to their inevitable birth. On this viewpoint they are examined as a damaging occurrence and in the process of terminology standardization they contain a focal direction of the work for their removal, by determining through them the standard term.
\end{abstract}

Keywords: antonymy, synonymy, terminology of economics.

\section{General issues}

Synonyms are different words with identical or similar meanings which constitute a rich class in Albanian language. Thus, we have two, three or more words that indicate the same thing, the same feature, the same action or the same phenomenon, such as, i zbrazët-bosh, ndikim-influencë. përvojë-eksperiencë, shmang-evitoj, tregti-pazarllëk. (Eng. empty-hollow, impact-influence, experience-experience, evade-avoid, trade-bargaining).

Synonymy, as a concept, in the general language as in any language, as well as in Albanian1 is viewed as a positive phenomenon, as an expression of the diversity and the wealth of language2. Synonyms, as a basis have a set of semantics, its semantic proximity, but also its semantic equivalents. The latter is like a basis for the absolute synonyms (binaries) where in the general lexicon they are at a limited quantity.

The causes of the occurrence of synonymous terms (binaries) of the synonymy in terminology are different:

- they can be created in the course of development and formation of terminology, when the effort is made to introduce the most suitable foreign or native term into the language. Cases of binary connections can be brought here, which may constitute the most extreme manifestations of the creation of synonymies in the relevant field, due to the competition of foreign terms as well and native ones in the stream of time, which is observed more in Albanian, like: fond i paprekshëm-fond i pandarë-fond i pandashëm; çmim sezonal-çmim stinor, (xhiro) likuide-(xhiro) me para në dorë (Eng. intangible fund-undivided fund-indivisible fund, seasonal price-seasonal price, (giro) liquid - (giro) cash).

- they arise as a result of the conceptual development; from the emergence of new concepts and the phasing out of old ones from language;

- during the efforts for the insertion of native terms into terminology which as a process can be evaluated in a twofold way:

As an overload of terminology, which creates confusion in communication, but also as a way of terminology perfection, where the authentic terms are really more convenient than the foreign ones and thus respond to the

${ }^{1}$ Memushaj, R. (2004). Hyrje në gjuhësi [Introduction to Linguistics]. Tirana: Dituria.

2Islamaj, Sh. (1985). Çështje të sinonimisë në gjuhën shqipe [Synonymy issues in Albanian]. Prishtina: Institution of Albanology. 
characters of the terms, like for example, single meaning, accuracy, etc.. As an example, in Albanian we may bring the gradual elimination of the binary units following the times until today, but also in their zigzag path: produkt-prodhim, (drejtim) unik $i$ ndërmarrjes-(drejtim) njësor $i$ ndërmarrjes (Eng. product-production, unique (direction) of the company- monistic (direction) of the company).

\section{The Manifestation of Antonymy}

As a result of antonymy, words pair into groups according to their semantic similarity. Each of these groups can be constructed according to some characteristic features:

- according to the opposition or proximity or similarity of words within a context;

- according to the scope of use;

- according to the lexical meaning of the word.

The antonymy appears as a linguistic phenomenon with a systemic character for the general language ${ }^{3}$, as well as for the terminology of economics ${ }^{4}$, since through it, connections from opposites are created; thus, it is a bonding phenomenon of meanings or concepts in opposition to each other. Regarding terminology, this phenomenon can occur in varying degrees depending on the character of the field.

This phenomenon appears even in the terminology of economics, especially in its basic vocabulary. As a rule, adjective units may oppose since they indicate quality, whereas nouns do less so because they indicate concrete objects: homogjen-heterogjen, uniform-jouniform, mikrostrukturë-makrostrukturë (Eng. homogeneous-heterogeneous, uniform- (not) uniform, microstructure-macrostructure).

As a rule, in the terms of compound words, their constituent elements oppose, but not the compound words with each other, e.g., in prodhim i lartë - prodhim i ulët (Eng. high production- low production) the two compound words do not oppose each other but the constituent elements do: i lartë - $i$ ulët (Eng. high - low).

In the composition of terms, terms can be elements themselves which oppose when the compound word is composed by two terms, or two common words may oppose, like for example, i madh - $i$ vogël (tek kapital $i$ madh kapital i vogël). (Eng. large - small (in large capital - small capital).

\section{The Formation of Antonymic Pairs in the Terminology of Economics with Prefixes of Opposite Meanings}

Here we will present some antonymic pairs, which have wider use in the terminology of economics:

jo-: (meaning 'un-', 'non-', 'in-', 'i' and 'ab': aftësi-joaftësi (Eng. ability-inability), bujqësor-jobujqësor (Eng. agricultural - 'un'or 'non'agricultural), ciklik-jociklik (Eng. cyclic - noncyclic), ekonomik-joekonomik (Eng. economical-uneconomical), fitimprurës-jofitimprurës (Eng. profitable-unprofitable), formal-joformal (Eng. formalinformal), industrial-joindustrial (Eng. industrial - nonindustrial), kalimtar-jokalimtar (Eng. transitional-intransitive), kapitalist-jokapitalist (Eng. capitalist-noncapitalist), klient-joklient (Eng. consumer-nonconsumer), kompetentjokompetent (Eng. competent - incompetent), kryesor-jokryesor (Eng. main-(not)main), likuid-jolikuid (Eng. liquid(non)liquid), mall-jomall (Eng. goods-(non) goods), material-jomaterial (Eng. material - immaterial), modern-jomodern (Eng. modern-(not) modern), natyror-jonatyror (Eng. natural - unnatural), nikoqir-jonikoqir (Eng. host-(un)host), normal-jonormal (Eng. normal-abnormal), objektiv-joobjektiv (Eng. objective-nonobjective), origjinal-joorigjinal (Eng. original-unoriginal), përcaktues-jopërcaktues (Eng. determinable-undeterminable), përdorues-jopërdorues (Eng. usable-unusable), praktik-jopraktik (Eng. practical-unpractical), prodhues-joprodhues (Eng. productiveunproductive), punëtor-jopunëtor (Eng. hardworking-(not) hardworking), real-joreal (Eng. real-unreal), rentabëljorentabël (Eng. profitable -unprofitable), tatimor-jotatimor (Eng. taxable-untaxable);

pa-: (meaning 'without', '-less' and 'un-'): i aftë-i paaftë (Eng. skilled-unskilled), me afat-pa afat (Eng. limitedunlimited), i ambalazhuar-i paambalazhuar (Eng. packaged-unpackaged), i besueshëm-i pabesueshëm (Eng. reliable unreliable), i caktuar- i pacaktuar (Eng. set/defined-undefined), i deklaruar- i padeklaruar (Eng. declared-undeclared), i dëmshëm- $i$ padëmshëm (Eng. harmful-harmless),i dobishëm- i padobishëm (Eng. useful - useless), fuqi- pafuqi (Eng. strength-without strength (impotent)), i formuar- i paformuar (Eng. formed-unformed), i fuqishëm- $i$ pafuqishëm

3Samara, M. (1985). Çështje të antonimisë në gjuhën shqipe [Antonymy issues in Albanian]. Tirana: Academy of Sciences of Albania. ${ }^{4}$ Pasho, H. (1986). Vështrim mbi disa shfaqje të shumëkuptimësisë, të sinonimisë dhe antonimisë në terminologjinë e ekonomisë [Overview on some appearances of polysemy, synonymy and antonymy in the terminology of economics]. Studime Filologjike [Philological Studies] Vol. 3. Tirana: Institution of Philology and Literature. 
(Eng. powerful-powerless), i gjobuar- $i$ pagjobuar (Eng. fined - not fined), i harxhuar- $i$ paharxhuar (Eng. consumed unconsumed), i informuar- i painformuar (Eng. informed-uninformed), i këmbyeshëm-i pakëmbyeshëm (Eng. exchangeable-unchangeable), $i$ konsumuar- $i$ pakonsumuar (Eng. consumed - unconsumed), i kontestueshëm- $i$ pakontestueshëm (Eng. contested-uncontested), i kontrolluar- $i$ pakontrolluar (Eng. controlled - uncontrolled), i korrigjuar-i pakorrigjuar (Eng. corrected-uncorrected), i korruptuar- i pakorruptuar (Eng. corrupt-uncorrupt), i krahasueshëm - i pakrahasueshëm (Eng. comparable-incomparable), i kualifikuar- $i$ pakualifikuar (Eng. qualified unqualified), i kushtueshëm- i pakushtueshëm (Eng. costly-uncostly), e normuar- e panormuar (Eng. normed(un)normed), e organizuar e paorganizuar (Eng. organized-unorganized), i paguar- i papaguar (Eng. paid-unpaid), $i$ qëndrueshëm- i paqëndrueshëm (Eng. stable-unstable);

zh- (meaning 'to undo smth. using 'un-' or 'de-'): bllokim-zhbllokim (block-unblock), dëmtim-zhdëmtim (injury / damage-compensation), vlerësim-zhvlerësim (Eng. evaluation/devaluation), i zhvilluar-i pazhvilluar (Eng. developed - undeveloped);

ç-(meaning 'i-'): i rregullt-i çrregullt (Eng. regular-irregular)

\section{Antonymic Formations with Words of Opposite Meanings}

aktive-pasive (llogari), aktiv-pasiv (i bilancit), bruto-neto (peshë), debi-kredi, deficit-suficit, e brendshme- jashtme (tregti), e madhe-e vogël (ndërmarrje, uzinë), e plotë-e pjesshme (papunësi), e thjeshtë- e ndërlikuar (punë),eksportim-importim, fitim-humbje, hyrje-dalje, individuale-kolektive (normë, punë), lidhje-zgjidhje (e kontratës), private-shoqërore (pronë), shitje-blerje, ulje-mbyllje (e llogarisë) (Eng.: active-passive (account), active-passive (of the balance), gross-net (weight), debit-credit, deficit-surplus, internal-external (trade), big-small (enterprise, plant), full-partial (unemployment), simple-complex (work), export-import, profit-loss, input-output, individual-collective (rate, work), bind-unbind (of contract), private - social (property), sale-purchase, reduction - closure (of the account).

\section{Manifestation of Synonymy}

There are different opinions about synonymy in terminology. The presence of synonyms within the terminological system is categorically denied by some researchers and is named as an occurrence which damages the terminology. Other researchers accept the synonymic character of the terms. About the phenomenon/occurrence of synonyms in the general literary language, other researchers do oppose the occurrence of doublets in terminology. These researchers, by bearing in mind the differentiation of semantic nuances in the scientific context consider that these semantic nuances with time will weaken and will level, therefore in the frame of the scientific context all synonyms are doublets.

It is obvious that the terminology of economics in Albanian as a terminology of a developing country, should be characterized, and indeed characterized by a multi variant of terms for naming different concepts, which appear in the form of binary pairs, but sometimes also in binary verses. If this terminology is viewed in terms of today's situation it can me noticed that in general the quantity of binaries has shrunk over time, especially in comparison with the past, when it was in the developing and consolidation process. In particular, after the 80's in Albania with the launch of a more organized work in the area of processing Albanian terminologies, the attempt was also made in the field of economy to albanize its terms, which was reflected in some textbooks and in particular in some dictionaries/glossaries directly or indirectly related to the field of economy, as, "Glossary of terms of political economy", "Glossary of Finance and Accounting" and other. In Kosova is published "Glossary of Business, Economy and Finance" in English-Albanian Albanian-English. In this case it should be emphasized that this work in the area of refining the terminology of economics, contributed in its use in textbooks and especially in the discursive practice.

In continuation we will present some examples of the manifestation of synonymy in the terminology of economics: asistencë sociale-kujdes shoqëror, (Eng. social assistance - social care), buxhetishtetit-buxhetshtetëror (Eng. the budget of the state - state budget), centralizim i financave-qendërzim i financave (Eng. centralization of finances - finance centered), çmim sezonal-çmim stinor (Eng. seasonal price- price determined by the season), çmime bazë-çmime të pandryshueshme (Eng. basic prices-fixed prices), decentralizim $i$ çmimeveshqendërsim i çmimeve (Eng. decentralization of prices), depozitë me afat-depozitë e kushtëzuar (Eng. term depositconditioned deposit), ekonomi shumëformëshe-ekonomi shumësektorëshe (Eng. diverse economy-multisectorial economy), fond i paprekshëm-fond i pandarë (Eng. untouchable fund-undivided fund), hua-borxh (Eng. loan-debt), $i$ likuiduar-i shlyer (Eng. liquidated-deleted), i zbrazët-bosh (Eng. empty-hollow), kursi valutë-kurs valutor (Eng. exchange value-exchange rate), likuidim-shlyerje (Eng. liquidation-deletion), likuidoj-shlyej (Eng. liquidatedelete), listë e pagesave-listëpagesë (Eng. pay-roll-pay-sheet), mall-artikull-send (Eng. goods-article-item), marzhë- 
shtesë tregtimi (Eng. added margin-trading), mbiprodhim-superprodhim (Eng. overproductionsuperproduction), mbyllje e llogarisë-ndalim i llogarisë (Eng. account closure-account ban), përvojë-eksperiencë (Eng. experience),prodhim-produkt (Eng. production-product), rabat-zbritje tregtimi (Eng. rebate-trading discount), saldo-mbetje llogarie (Eng. equity-account residue), shmang-evitoj (Eng. evade-avoid), shpenzimet $e$ buxhetit-shpenzime buxhetore (Eng. budget expenses-budget expenditure), tatimfitimi-tatimfitim (Eng. tax for profitprofit tax), tregti-pazarllëk (Eng. trade-bargaining) etc..

Unfortunately, it can be noted, that after the opening up of Albania and Kosova with the world, especially after 2000 , introducing the process of market economy and globalization there is some limitation in the standardization work of the field in question which has led either to the cessation of work to remove binary terms or to the return to foreign terms, especially derived from English (or parallel use of foreign as well as Albanian terms).

\section{Conclusion}

Semantic phenomena in terminology have to be treated with the specificity of their appearance in this lexical subsystem, compared with the general lexicon. From this perspective it is important to underline that the characteristics of occurrence of the synonymy and the antonymy can be brought out fully, when viewed within a particular field of knowledge, as is in our case the terminology of the field of economics.

By looking at the terminology in question from the view of occurrences of the phenomenon of synonymy, it appears that the Albanian terminology of economy is overloaded with synonymous terms even in its functional condition today, especially in the subfield of economy, finance, etc.

Antonymy as a semantic phenomenon even in the terminology of economics, different from the semantic phenomena above; is closer as a phenomenon with the general lexicon since it appears as a positive phenomenon, motivated by the systemic character of terminology. In the economics terminology, antonyms usually are revealed as part of compound words/phrases, like, i lartë- $i$ ulët, i madh- $i$ vogël tek prodhim i lartë - prodhim i ulët, kapital i madh - kapital i vogël (Eng. high - low, large - small, for high production - low production, large capital - small capital).

\section{References}

Dhrimo, A. \& Memushaj, R. (2011). Fjalor drejtshkrimor i gjuhës shqipe [Albanian Orthographic Dictionary]. Tirana: INFBOTUES.

Duro, A. (2009). Termi dhe fjala në gjuhën shqipe [Term and word in Albanian]. Tirana: Fan Noli.

Fjalor $i$ termave të transportit shqip-anglisht-frëngjisht-rusisht (2002) [Dictionary of transport Albanian-English-French-Russian]. Tirana: ASHSH Institution of Linguistic and Literature.

Gorani, H. (2009). Problemet kuptimore në terminologjinë ekonomike [Semantic problems in economic terminology] Gjendja dhe zhvillimi $i$ terminologjisë shqipe, probleme e detyra [Situation and development of Albanian terminology, problems and tasks] (pp. 136142). Scientific Conference. Tirana: Kristalina KH.

Memushaj, R. (2004). Hyrje në gjuhësi [Introduction to Linguistics]. Tirana: DITURIA.

Pllana, S. (2009). Vëzhgime mbi terminologjinë e fushës së "mekanikës së zbatuar në makina" sisistem leksikor-konceptor [Observations on the terminology of the field of "applied mechanics of machines" as lexical-conceptual system]. Gjendja dhe zhvillimi i terminologjisë shqipe, probleme e detyra [Situation and development of Albanianterminology, problems and tasks] (pp. 212-221). Scientific Conference. Tirana: Kristalina KH.

Pllana, S. (2003). Një analizë e metodave të punës praktike të terminologjisë [An analysis of practical methods of terminology].TEKNIKA Revistë profesionale dhe shkencore për teori dhe praktikë,[TEKNIKA-Professional and scientific journal for theory and practice], Year I, no. 3, 35-44.Ferizaj: University of Prishtina, Technical High School Ferizaj.

Pllana, G. \& Pllana, S. (2012).A conceptual connections on a word and term level in the terminology of theoretical mechanics (in Albanian and English).trans \& MOTOAUTO'12 20thInternational scientific and technical Conference on transport, road-building, agricultural, hoisting \& hauling and military techniques and technologies, Varna, Bulgaria.

Pllana, S. \& Pllana, G. (2012). Studies undertaken in the field of terms and coverage mechanics as its respective glossary of the Albanian language. Trans \& MOTOAUTO'12 20th International scientific and technical Conference on transport, road-building, agricultural, hoisting \& hauling and military techniques and technologies, Varna,Bulgaria.

Rexha, N. (2009).Fjalor i biznesit, ekonomikës dhe finances anglisht-shqip,shqip-anglisht [Dictionary of Business, Economics and Finance English-Albanian. Albanian-English]. Prishtina: ASAU.

Sager, J. (1990).A practical course in Terminology Processing. Amsterdam, Philadelphia: John Benjamins.

Samara, M. (1985).Çështje të antonimisë në gjuhën shqipe [Antonymy issues in Albanian]. Tirana: Academy of Sciences of Albania.

Samara, M. (1999). Fjalor $i$ antonimeve në gjuhën shqipe [Dictionary of antonyms in Albanian]. Tirana: Academy of Sciences of Albania.

Thomaj, J. (2006). Leksikologjia e gjuhës shqipe [Lexicology of Albanian]. Tirana: BOTIMET TOENA. 